\title{
Research on the constructing path of Hubei agricultural informatization
}

\author{
Li Zhou ${ }^{1, a^{*}}$, Dan Jin ${ }^{2, b}$ \\ ${ }^{1}$ Wuhan Donghu University, Hubei Provincial Collaborative Innovation Center of Agricultural \\ E-Commerce (under construction), Wuhan, Hubei, China \\ ${ }^{2}$ Wuhan Donghu University, Wuhan, Hubei Province, China \\ aemail: 13308658509@163.com
}

Keywords: Hubei; agricultural informatization; path

\begin{abstract}
Hubei province, as the national rural informatization demonstration province, has made significant progress in the construction of agricultural informatization, but there are still some problems, for example, agricultural informatization service object is not mature, agricultural information excavating is not deep enough, and etc. Therefore, the agricultural informatization in Hubei province should be on the premise of government guiding and market participation to improve the ideological understanding, cultivate the subject of new type of agricultural management, intensify agricultural information research, and from the construction of soft environment to the formation of supply and demand force about agricultural information to promote agricultural informatization construction in Hubei province.
\end{abstract}

\section{Introduction}

The party central committee in-depth analyzed current social and economic development in our country, and made important strategic deployment in the 18th National Congress of Communist Party of China (CPC)," to promote industrialization, informatization, urbanization and agricultural modernization synchronous development", which highlights the importance of agricultural modernization and informatization. What is the agricultural modernization? Xu Gengsheng pointed out that agricultural modernization is to equip agriculture with modern science and technology, and to organize and manage agriculture by means of advanced scientific methods in his research report -The historical experience of agricultural modernization and its enlightenment to China. Therefore, the agricultural modernization whose content changes with continuous development of science and technology is keeping pace with times. 21 st century, a informational age, in this time, it's necessary to regard informatization as the important part of developing modern agriculture with the help of agricultural informatization.In 2012, the ministry of science and technology, organization, industry and information technology jointly sent a letter to Hubei province people's government, five provinces including Hubei province were determined to carry out national rural informatization construction pilot. Hubei province government also lunches work energetically, releasing development planning of modern agricultural in Hubei province (2013-2014) and making top-level design for promoting agricultural modernization-one of the five modernization.

\section{Achievement of agricultural informatization construction in Hubei}

The pilot work of rural informatization demonstration province construction isn't the beginning of Hubei agricultural construction. In fact, where there's agricultural information, there's dissemination and utilization of agricultural information; as long as there is informational technology, some of land will be used in agriculture. However, agricultural informatization construction will make more repaid and significant progress under the government's promotion.

The comprehensive coverage of the construction of rural basic network in Hubei province. Until the end of 2013, Hubei Province achieved 100\% communication by telephone in administrative village, small towns reached $99.8 \%$ of broadband coverage rate , and administrative village attained 
$47 \%$. By the end of 2010, population's comprehensive coverage rate of whole provincial broadcasting and television respectively reached $98.10 \%$ and $98.11 \%$. More than 20 households have realized that every village accessed radio and television by natural village; Radio and television wireless coverage project of the broadcast centre and provincial TV station have completely completed; All cities and counties in the province, Shennongjia and all villages and towns, 91.1\% of administrative villages realized cable radio and television optical cable network.

Omnibearing expanse of agricultural information media construction.Agricultural information media includes newspaper, radio, television, internet and other media. Agriculture in Hubei newspaper was issued in January 2008, which is an authoritative agricultural science and technology paper media, whose every periodical is 130 thousand. It disseminates modern agricultural information and guides the famer to get rich, has a great influence among the readers. In august 2011, rural broadcast and ridge channel was launched in Hubei broadcast station to spread knowledge of agricultural science and technology. Ridge channel's "words agriculture point of gold", "intelligence station on ridge", "weather stations on ridge" and etc, those programs have a very strong pertinence and service for agricultural population and agricultural materials enterprise. In order to adapt to the development of information technology and the change of the channels that the masses receive information, Hubei province agriculture department set up agriculture information network, in addition to reporting agricultural government affairs, also spread agricultural practical technology and Chinese lunar calendar to society to help farmers develop agricultural production. The rural smarten hosted by national rural information demonstration province construction leading group office of Hubei offers information, agricultural technology, people's livehood, industry and business channel. The website disseminates not only social hot issues about which peasants concerned but also agricultural skills and experts answer; Not only provides supply and demand information and price forecasting of agricultural products, there are also countryside supermarket and etc.

Agricultural science and technology information multi-channel promotion in Hubei Province. For strengthening the agricultural science and technology information to enter into the countryside, Hubei province actualizes the ombudsman system, designates technical experts, and enrich the science and technology team of each county. Hubei agricultural science and technology Institute counties and experts in various county and city take advantage of the rich agricultural expert resources of Hubei province to primarily structure agricultural science and technology extension mode of the trinity of agriculture and science and education .Hubei opened "12316" provincial " agriculture, country, persants" hotline platform, "agricultural information interflow" and "mobile news" three rural informatization service construction.

\section{The problems exist in the agricultural informatization construction when it is promoted in Hubei}

Although some achievements have been made in promoting agricultural informatization in Hubei province, it is only relative to yesterday .Besides America, Japan, Europe, there are gap compared with other domestic provinces. Liguo Cui, in Evaluation of the development level of agricultural informatization in various regions of China based on clustering analysis ,by making use of the questionnaire data of the development strategy of agricultural information development strategy of the ministry of agriculture in 2012,established evaluation index of development level of agricultural informatization, meanwhile, agricultural information development level is divided into extraordinary high, relative high, high, general low and very low by utilizing cluster analysis. The level of agricultural informatization in Hubei province was classified as general . While, according to the dates of 2008, Dr Wang Zhen draw a conclusion that Hubei ranks 8th at external environment index of agricultural informatization, 5th at agricultural information talent index, 13th at agricultural information industry index , 11th at application index of agricultural information technology, 10th at agricultural information infrastructure index, 8 th at Index of agricultural information resources in his postdoctoral research report-Evaluation of the development level of agricultural informatization in various regions of China based on cluster analysis. According to the weight of each sub-item index 
agriculture informationization, he calculated comprehensive index of agricultural information development level, and Hubei rank 9th. Obviously, from 2008 to 2012, people hardly noticed the outstanding performance of agricultural informatization level in Hubei Province .On the contrary, Fujian and Ningxia made a spurt of progress. At present, we have to cogitate where the matters lie.

Agricultural information service object is fully-fledged. Our government has spent a lot of time, energy and funds to promote the construction of agricultural information, but only when this construction acts on agricultural subject can it show utility. Agricultural information service object should be the primary service object of agricultural informatization. Hubei province is a big agricultural province, but it generally runs Small-scale farm production.

Small-scale farm production has little demand for agricultural information and lacks of active learning initiative they are unwilling to read the newspaper, and TV is mainly used for entertainment. These peasants are generally old, weak, sick and disabled and low education, most of them only have primary or middle school level they acquire the information of agricultural production from the older generation or neighborhood's precept and experience. The utility of internet is extremely low in agricultural production and sales. All of those make the agricultural information that government had painstakingly managed have no obvious substantial effect.

It's not thorough enough that various media excavate agricultural information. As far as this problem's concerned, there are several aspects: (1) The agricultural information released by various media trend towards advolution, which lack of characteristics. They have identical information and there is even a phenomenon of plagiarism, which is not conducive to the healthy development of the information industry and it is not in accordance with the provisions of the law of intellectual property rights. (2) The varieties of agricultural information released by media are drab and short of feature. Hubei Province is known as "the province of a thousand lakes", "thoroughfare of nine provinces", its aquatic products are exceedingly characteristic. Wuchang fish, lotus root, shrimps and crabs are fame the whole nation over, but the real-time information about characteristic agricultural products is extraordinarily limited.3 Agricultural products yield and price are of deficiency of predicted information. Output and price are two elements in the market, but it is very difficult to find predictions for the future in media, and the publishment of past output is always tardy. Some media's column about agricultural product price forecasting is useless, and some predictions make people skeptical. (4) Publishment of international agricultural information are destitute. The earth had become global village for the development of science and technology; International agricultural relative change will affect agricultural production of domestic province. Although Hubei province is an inland province, it also bears the foreign agricultural competition, and has the ability to rush out of the country, even has been out of the country. (5) Agricultural information collection mechanism is inadequate. In fact, the reasons of the previous questions quite connect with the lack of agricultural information collection mechanism. Agricultural information collection spots in Hubei Province are limited, the distribution of those spots are restricted to cities and suburbs. Neither does the remote mountainous have agricultural information service station, nor service personal. They are short of firsthand information of agricultural fields.

Agricultural information service system needs to be improved. Who will provide agricultural information services and how to build agricultural information service system ?Those are significant problem in promoting agricultural informatization services. Hubei province is mainly administrative push type at present. Led by the office of science and technology, Hubei province set up construction leading group-----national rural agricultural information demonstration Province and the office administrator is the office of science and technology. This arrangement is highly effective for the technological innovation of agriculture, but will it accord with agricultural actual demand or not? Agricultural information is a highly specialized field, which requires that leading group understands informatization technology and agricultural production and rural livehood. Consequently, as a professional agricultural, the provincial agriculture department and provincial academy of agricultural sciences need to be occupied with constructing agricultural informatization.

It's not enough with government's push, only with motivating market force can agricultural informatization service be comprehensive and effect. Now Mobile, Unicom, Telecom and etc , have 
participated in this service system, such as the rural information service platform "agricultural information interflow" of Hubei mobile ,SMS service project" agricultural new time and space" of Hubei Unicom, and "wing agricultural mobile newspaper" of Hubei Telecom. But those channel of Information dissemination with strong administrative color become the selection of that leaders strive for administrative achievement.

\section{The selection of agricultural informatization construction in Hubei}

The guiding of ideology of agricultural informatization construction in Hubei. leading by government, participating by market, electronic business as an impetus. Agricultural informatization construction in Hubei has features of large investment and long term investment. Therefore, it is necessary for government to do infrastructure construction accordingly. Owing to the agricultural information has a wide coverage and dynamic change. The collection of agricultural information is quite hard, thus, making use of the administrative system to finish it is convenient .In addition, under the environment in China whose intellectual property protection need to be improved, information is easily stolen without cost, which make information has feature of public goods. So the government is the only provider of information.

What's more important, the government leads the market power to do agricultural information construction in Hubei, except for becoming the provider of information product. That it is useless for government to do everything has historic lessons. The invisible hand of market is regarded as the most efficient in the distribution of resources. The agricultural is weak industry, government should publish the policy which is tax preferences and financial subsidies to lead the market itself to enter, and develop it to become competitive individuality which can bring the development of agricultural informatization .There are experiences showing that agricultural electronic business is a part of market individuality in agricultural informatization construction in Hubei which can be well operated. Electronic business provides a platform for achieving "Thrilling jump" in agricultural production. And the success in "Thrilling jump" is bound to scatter positive energy for other agricultural questions. Therefore, it is possible for agricultural informatization construction under the market's participation, it also be efficient. The market information of agricultural production is the basis and impetus in agricultural informatization construction in Hubei.

Choice of ways of agricultural informatization construction in Hubei Province. Only when the new things gain social recognition can it be widely used, and if the agricultural informatization constructions intend to obtain remarkable effect, they have to get the full support of the whole society. Government at all levels demand for improving cognition of the connotation and extension of agricultural informatization, attaching great importance to the construction of agricultural information from energy to financial resources, In addition, doing a good job in propaganda of public opinion to inspire construction, setting up a typical case, setting policy to guide related agricultural units and personnel, and forming a long-term mechanism for the construction of agricultural imformatization. Besides, they have to do a good job in education and training work of farmers, encourage them to try to produce with the help of informatization technology, and actively cooperate with other departments' informatization construction work. From the government to the farmers and from policy to action, create a good soft environment for the construction of agricultural informatization.

One of the reasons about the stagnant agricultural informatization lies in the lack of demand, but cultivating new agricultural economic entities provide the forces of demand for the construction of agricultural information. New type business subject is agricultural business entities that, are in under of household contract management system, has large-scale management, high degree of intensification, strong competitiveness and professional farmers who are literate, skillful and good at management. Practice shows that new type business subject is the representative of advanced productive forces, and the main force of pushing agricultural transformation and upgrading, agricultural efficiency and increasing income. The characteristics of the new type of agricultural management main body have decided that he has the ability to participate in the construction of agricultural information. They demand a large amount of information, the marginal and total benefit 
that information produces are tremendous. However, there exists some problem, such as the low proportion of new agricultural business entities, the mild strength, the aging of farmers, fragmentary land management system and other issues. Thus it can be seen that it is vital to increase financial support, implement tax incentives, and strengthen agricultural credit support for the cultivation of new agricultural business entities.

Agricultural information construction can not be separated from the continuous in-depth study of information technology, the research results are the source of informatization construction's sustained development. Certainly, scientific research on the supply of agricultural information construction in Hubei province is not only stay in the information technology innovation, but also need for information technology in conjunction with the application research of agricultural characteristics of Hubei Province. A large number of colleges and universities in Hubei Province is bristly, and the quantity of scientific research institutes are tremendous, Huazhong Agricultural University and Hubei Academy of Agricultural Sciences are the representative of the high strength in agriculture. These departments and units should strengthen the research on theory and application of agricultural informatization construction in the province, foster comprehensive talents who understand both agriculture and information technology in order to provide scientific research achievement and scientific and technical personnel for Hubei provincial agricultural informatization construction.

\section{Conclusions}

(1)Improving the ideological understanding of agricultural information construction to provide a good soft environment.

(2)Cultivating new agricultural business entities to provide the demand for the construction of agricultural information.

(3)Strengthening scientific research to provide supply force for agricultural informatization construction.

\section{Acknowledgments}

This work is supported by the construction of agricultural information evaluation index system in Hubei Province.

\section{References}

[1] Brush, Heidi Marie. Netwars: Information technologies, global politics and the reappropriation of space. Dissertation Abstracts International.

[2]Cui Liguo, Li Jin, Liuli Hong. Based on the clustering analysis of Chinese regional agricultural informationization development level evaluation [J]. Agricultural science of Jiangsu, 2014 (9): 463-464.

[3] Economizes, Nicholas. The Economics of Networks. International Journal of Industrial Organization.1999, 675 699

[4] Wang Zhen. Research on the mode of advancing agricultural informatization in different regions. Postdoctoral Research Report of Chinese Academy of Agricultural Sciences. 2011.

[5] Weon-sik Hahn. Development and Use of Information Technology in Agriculture in Korea, Beijing: China Agricultural Scientific Press, 2002

[6]Yang Li. Study on Agriculture Websites' Operation pattern In the Course of Agricultural Informatization in China. 2004 CIGR International Conference.

[7] Yang Wanjiang, Xu Xingming. Agricultural modernization evaluation [M]. Beijing: social sciences academic press, 2001. 